with the denser material on the concave side; at least this would ordinarily take place. But such a bend in one plane is changed to a twist whenever the proper forces are present. In the case before us, we have not only the proper forces to cause a twist but also to give the motion constancy of direction, i.e., with watch hands. These forces are found in the spiral arrangement of the material. In this case we should expect a waving or serpentine bend rather than a close twist. The fact that many cells are found, after applying reagents, in all stages from a beginning bend in one plane to a wavy twist, leads to the conclusion that this is, perhaps, the principal force of torsion when the lumen is very eccentric.

It is probable that both these causes act in conjunction to produce the generally resulting perfect torsion.- L. Murbach, Centrai High Schoo', Detroit, Mich.

\title{
SOME NEW SPECIES OF WYOMING PLANTS.
}

Silene Tetonensis. - Stems several, somewhat cespitose from a multicipital caudex, Io-2 $5^{\mathrm{cm}}$ high, I-7-flowered: minutely pubescent throughout, glandular above and often throughout, the leaves often glabrous except on the margins: leaves connate at base and sheathing by somewhat scarious membranes, the petioles often sparsely ciliate; the radical long-petioled, linear or narrowly oblanceolate, $2-8^{\mathrm{cm}}$ long, ${ }_{2-6}{ }^{\mathrm{mn}}$. wide ; the cauline linear or the lowest pair narrowly oblanceolate: calyx obovoid, $7-10^{\mathrm{mm}}$ long, with 10 purplish nerves, these anastomosing somewhat near the summit, 5 -toothed, the teeth rotund or rhomboid-triangular, obtuse with very broad membranous margins: petals $9-12^{\mathrm{mm}}$ long, greenish-white or rose-color, more or less exserted ; the claw $3^{\mathrm{mm}}$ broad, spatulate, with the margins entire or bluntly toothed near the summit, not at all auricled, 3 -nerved, the nerves branched and anastomosing in the limb; this $3^{\mathrm{mm}}$ long, as broad as the claw or generally a little narrower, with no lateral lobes, emarginate or cleft to the middle, the lobes entire and rounded, the appendages much broader than long and bluntly toothed : stamens nearly as long as the claws of the petals, the filaments glabrous; styles $3, \mathrm{I}^{\mathrm{mm}}$ long: carpophore very short.

Related to the western $S$. Watsoni, but is readily distinguished from that by its broader radical leaves and very different petals. 
The type is no. 6521 from the high grassy slopes of the Teton mountains, August I6, I 899 ; also no. 6684 from Dunraven peak in the Yellowstone park, August 27.

Heuchera saxicola.- Scape, petioles, and inflorescence villous and viscid-glandular, the leaves sparsely so: leaves oval to rotund, truncate or subcordate at base, doubly and incisely crenate with obtusish teeth, $2-4^{\mathrm{cm}}$ long, on petioles $4-9^{\mathrm{cm}}$ long : scapes slender, $2-4^{\mathrm{dm}}$ high, with two diminutive bract-like leaves near the summit: spike simple, often interrupted below, $3^{-6^{\mathrm{cm}}}$ long; bracts ovate in outline, acuminate, 3 -cleft to nearly entire and rhomboid, very ciliate on the margin, frequently tinged with violet, 6-8 $8^{\mathrm{mm}}$ long: calyx campanulate, about $7^{\mathrm{mm}}$ long, very pubescent and glandular, villous at base, divided to about the middle; the tube adnate to the ovaries for slightly over half its length; the lobes unequal in size, ovate or oval, obtuse, white and petaloid: petals wanting: filaments from triangular to subulate, $\mathrm{I}^{\mathrm{mm}}$ or less in length: capsule ovoid : seeds oval, hispid, brown.

$H$. saxicola is a near relative of $H$.ovalifolia Nutt., to which it is apparently referred in the recent published Catalogue of the Flora of Montana, for a specimen, collected by Rydberg and Bessey in the Spanish basin, belongs to this species. Referring to the original description, we find that $H$. ovalifolia is "wholly destitute of villous hairs," a negative character which at once excludes the plant here described. H.ovalifolia is originally from the region of the Columbia river, and is quite fully described in Howell's Flora of Northwest America. As here characterized, it has lanceolate and laciniate bracts, while in ours they are ovate in outline and either rhomboid or 3-cleft. The calyx is also described as tubular and with lanceolate lobes. In H. saxicola, on the other hand, the calyx is rather campanulate and the lobes broader.

Type, no. 5687, Undine falls in Yellowstone park, July 6, I899; also, no. 2822, Little goose creek cañon, July I 7, I 896 .

Saxifraga cognata.-Cespitose, the numerous short, erect stems $\left(\mathrm{I}-3^{\mathrm{cm}}\right.$ long) forming dense cushions, the lower part of the stems covered with old leaves: leaves imbricated, oblong-linear to lanceolate, cuspidate, $5^{-10^{\mathrm{mm}}}$ long, hispid ciliate on the margins, otherwise glabrous: flowering stems slender, about $\mathrm{I}^{\mathrm{dm}}$ high, sparsely covered with short purple-tipped hairs, as also the pedicels of the flowers, bearing several linear oblong leaves, these $3^{-5^{\mathrm{mm}}}$ long and naked on the margins, or nearly so : inflorescence cymose, 5-7-flowered, seldom 9 : calyx divided two thirds to three fourths; the lobes ovate, obtuse, or

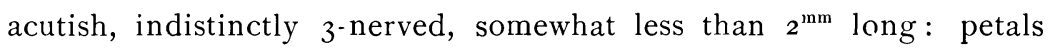


elliptic, $4-5^{\mathrm{mm}}$ long, white, tinged with yellow toward the base, the upper half with purple dots, 3-nerved, the lateral ones arising near the base and extending to near the apex: ovaries united their whole length, the slender, conical styles more or less divergent.

This includes all of the so-called $S$. bronchialis of the Rocky mountains, and perhaps also of the mountains of the Pacific states. S. bronchialis, which is originally from Siberia, is everywhere described as having lanceolate sepals and orange-dotted petals, while our plant has ovate sepals, and petals quite prominently dotted with purple.

No. 555 I, from Golden gate in the Yellowstone park, June 28, I899, may be taken as the type of this species.

Ribes saximontanum.-A low shrub; spreading stems about $6^{\mathrm{dm}}$ long, more or less bristly, with straw-colored and shreddy bark; infra-axillary spines three together, stout, $8-\mathrm{I} 2^{\mathrm{mm}}$ long : leaves orbicular or broader, truncate at base, 3-lobed half way to the base, the two lateral lobes again somewhat 2 -lobed, the lobes with obtuse or acutish teeth, very finely pubescent on both sides or glabrate, $6-20^{\mathrm{mm}}$ broad : flowers $\mathrm{I}-3$, axillary, about $\mathrm{I}^{\mathrm{cm}}$ long: calyx cylindraceous, glabrous, white tinged with violet: the tube $2^{\mathrm{mm}}$ broad or less, $4^{\mathrm{mm}}$ long, villous within; the lobes oblong, minutely toothed at the rounded summit, slightly shorter than the tube: petals cuneate-spatulate, toothed at the broad summit, about $2^{\mathrm{mm}}$ long: stamens included, the anthers oblong and obtuse: style divided half way to the base, villous: berry globose, smooth, reddish-purple, 6-1 $\mathrm{o}^{\mathrm{mm}}$ in diameter.

An excellent species, quite different from its southern relative $R$. leptanthum, from which it is readily distinguished by its bristly stems, glabrous whitish calyx, and divided villous style. It is an inhabitant of high, open slopes.

Type. no. 5542. Golden gate in Yellowstone park, June 28, I899; also no. 695, Garfield peak, July 29, 1894, by Aven Nelson.

Rosa grosse-serrata.- Much branched, 6- $18^{\mathrm{dm}}$ high, with occasional short prickles (less than $5^{\mathrm{mm}}$ long) or wholly unarmed, the branches purple and somewhat glaucous; stipules usually broad, $\mathrm{I} 2-20^{\mathrm{mm}}$ long, entire or minutely glandular-toothed, the free ends triangular ovate, acute, or acuminate, usually minutely resinous dotted and finely pubescent: leaves $5-7$-foliolate; the leaflets nearly sessile, the terminal petiolulate, elliptic to narrowly and cuneately obvate, sharply and coarsely serrate for about two thirds their length, $2-4^{\mathrm{cm}}$ long, glabrous above, sparsely and very finely pubescent and minutely resinous dotted (under 
a strong lens) beneath as also the rachis: flowers in clusters of two to four at the ends of the branches or solitary: sepals entire, linearlanceolate, attenuated, the tips only slightly dilated, sparsely pubescent on the back and occasionally hispid-glandular along the margins; petals unknown ; fruit globose, perfectly smooth, ak out $\mathrm{I}^{\mathrm{mm}}$ in diameter.

Apparently intermediate between $R$. pisocarpa and $R$. Woodsii. From the former it differs in its stouter branches, in the minutely resinous lower surfaces of the leaves, and in the larger and more coarsely toothed leaflets. From the latter one cannot so easily find characters by which to distinguish it, yet it is so different in appearance that its separation as a distinct species seems to be justifiable. The so-called $R$. Woodsii of the Rocky mountains is a much lower plant, and has leaflets only $2^{\mathrm{cm}}$ long.

The following collections of this species are at hand: no i creek, August 27, 1894; no. 6787 (type), Madison river in the Yellowstone park, August 30, I899; both by Aven Nelson.

Lupinus ramosus. - Stems several from a woody caudex, $2-4^{\mathrm{dm}}$ high, branched, with divaricate branches, these simple and terminating in short few-flowered racemes: stems and petioles with two kinds of pubescence, finely canescent and sparsely villous with spreading hairs : leaves 5-8-foliate, the lower half the length of the petioles, the upper equaling them; leaflets narrowly oblanceolate, obtuse to acute, usually mucronate, densely soft-silky on both sides, $2-4^{\mathrm{cm}}$ long, $5-9^{\mathrm{mm}}$ wide : racemes short-peduncled, $3-5^{\mathrm{cm}}$ in length, in fruit a little longer : bracts ovate or lanceolate, about $2^{\mathrm{mm}}$ long: flowers somewhat verticillate or scattered, about $\mathrm{I}^{\mathrm{cm}}$ long; pedicels $2-3^{\mathrm{mm}}$ long, in fruit $5^{\mathrm{mm}}$; calyx bracteolate, densely silky, as also the pedicels, the lower lip a little longer than the upper, which is slightly notched: vexillum very silky on the back, the central portion yellowish-white, otherwise pale blue or lilac; wings pale blue, slightly longer than the vexillum; keel light-colored, ciliate on the margin except at the very tip: pod silky, 3-5-seeded.

Characterized by its branching habit, short and few-flowered racemes, and the two kinds of pubescence.

The type, no. 6576, is from dry banks and benches on Snake river, Yellowstone park, August 20, 1899.

Lupinus humicola Tetonensis. - Stems one or more from the same root, simple $3^{-6^{\mathrm{dm}}}$ high, including the racemes, 3-5-leaved; leaflets acute or obtuse and mucronate, glabrous on the upper surface or 
sparsely strigose, $5^{-9^{\mathrm{cm}}}$ long, $8-\mathrm{I} 8^{\mathrm{mm}}$ wide : raceme $4-\mathrm{I} 2^{\mathrm{cm}}$ long, mostly only $4-5^{\mathrm{cm}}$.

No. 634 I, Teton mountains, August I6, I899.

Antennaria fusca.- Loosely cespitose : stolons about $5^{\mathrm{cm}}$ long: stems slender, $\mathrm{I} 2^{\mathrm{cm}}$ high or less: leaves canescent or tomentulose on both sides, the older ones becoming glabrous ; the radical and those of the stolons spatulate, indistinctly mucronate, $15-22^{\mathrm{mm}}$ long; the cauline linear, $2-4{ }^{\mathrm{mm}}$ wide, the lower somewhat broadened upwards and acute, the upper acuminate : heads $3^{-1} 3$, on short pedicels in close clusters or loosely corymbose, and the head or heads of the lowest pedicel, which is often $2-3^{\mathrm{cm}}$ long, usually overtopping the rest: involucres about $6^{\mathrm{mm}}$ high : bracts (pistillate) in about two series, the lower half bright green and sparsely woolly, the upper portion brown or greenish-brown, oblong, obtuse, more or less serrate.

In habit and general appearance the species here described would suggest $A$. aprica Greene, yet it is not even a very near ally of that. Its darkcolored bracts, slender stems, and the dull and light indument of the leaves easily separate it specifically from Professor Greene's species.

The type is no. 6356, growing on dry bottoms and in open woods on Lewis river, Yellowstone park, August 8, 1899.

Antennaria oblancifolia.-Cespitose : stolons very short: stems slender, ${ }^{\mathrm{cm}}$ high or less : radical leaves oblanceolate, those of the stolons narrowly so, acute, mucronate, about $2^{\mathrm{cm}}$ long, sparsely canescent to glabrous above, canescently tomentose below: cauline leaves linear or oblong-linear, the lower acute, the upper acuminate: heads 4-I3, in close racemose or paniculate clusters : involucres (staminate) $4^{\mathrm{mm}}$ high, the herbaceous portion of the bracts sparsely woolly, the scarious portion oval, obtuse, brownish, or white.

This is near to $A$. racemosa, but it is so strikingly different from that in the size and outline of its leaves that it must stand as a distinct species.

It is represented by a single collection in which all the plants are staminate, secured on an open, once wooded slope, near Mammoth hot springs in he Yellowstone park, July 3, I 899, no. 5640.

Gnaphalium thermale.-Low, I-2 ${ }^{\mathrm{dm}}$ high, branched from the base, the stems more or less branched throughout or simple to near the summit: stems and leaves grayish woolly: radical leaves oblanceolate, about $35^{\mathrm{mm}}$ long, the cauline narrowly oblanceolate to linear, $\mathrm{I}-3^{\mathrm{cm}}$ long: heads sessile in small glomerules terminating the branches: 
involucres $4-5^{\mathrm{mm}}$ high : bracts dull white, from ovate in the outer to linear in the inner, obtuse or acutish, nearly all apiculate.

A northern ally of the Texan G. Wrightii.

Collected on the geyser formations of Norris geyser basin in the Yellowstone park, July 25, 1899, no. 6139.

UNIVERSITY OF WYOMING,

Elias Nelson. Laramie.

\section{SOME NEW NORTH AMERICAN MOSSES.}

\section{(WITH PLATE XI)}

IN July 1898 the writer, in company with Mr. James Blake, made a vacation trip into northwestern Montana, during which we collected especially mosses and hepatics. The region visited is reached by the Great Northern railway, which we left at Belton, thirty miles east of Kalispell. Thence we made our way to the north end of lake McDonald, some twenty miles north, where we pitched our permanent camp. The region visited is especially interesting because of the several glaciers which nestle among the precipitous mountain peaks. We visited only one of these, Sperry glacier, at the base of which we found several European mosses heretofore not reported for the United States, as well as some new species closely related to certain alpine species of the old world. So far as determined the material collected includes I 40 species of mosses and 20 species of hepatics. The publication of a full report is delayed for various reasons, and it is deemed desirable to publish here only the most important part of the report as far as prepared. A more detailed account of this region, botanically as well as geologically very interesting, may be found in the September number of Bulletin of the American Bureau of Geography.

Dicranoweisia subcompacta Card. et Thér., sp. nova.-Dense pulvinato-caespitosa. Caulis simplex vel parcissime ramosus, $6-8^{\mathrm{m} ! n}$ altus, dense foliosus. Folia madida suberecta, sicca crispatula, I-I. $5^{\mathrm{mm}}$ longa, oblongo-lanceolata, acuminata, subacuta vel obtusiuscula, superne, canaliculata, nervo basi attenuato usque ad apicem producto vel paululum infra evanido, marginibus inferne planis, superne inflexis, integerrimis, cellulis irregulariter quadratis vel subrectangularibus, inferioribus laxioribus, juxta costam linearibus, alaribus distinctis, subinflatis, fuscis. Caetera ignota.- Plate XI. 